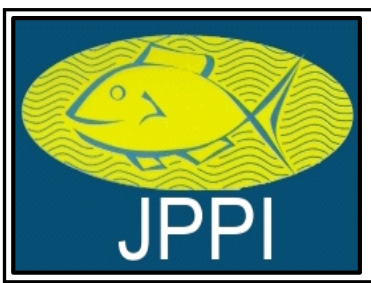

Tersedia online di: http://ejournal-balitbang.kkp.go.id/index.php/jppi

e-mail:jppi.puslitbangkan@gmail.com

JURNAL PENELITIANPERIKANANINDONESIA

Volume 26 Nomor 2 Juni 2020

p-ISSN: 0853-5884

e-ISSN: 2502-6542

Nomor Akreditasi RISTEKDIKTI: 21/E/KPT/2018

\title{
KARAKTERISTIK STRUKTUR KOMUNITAS IKAN KARANG TARGET DAN INDIKATOR DI PERAIRAN TAMAN NASIONAL KOMODO
}

\section{CHARACTERISTICS OF COMMUNITY STRUCTURES FOR TARGET AND INDICATOR REEF FISHES IN THE WATERS OF KOMODO NATIONAL PARK}

\author{
Ayuningtyas Indrawati ${ }^{\star 1}$, Isa Nagib Edrus ${ }^{2}$ dan Tri Aryono Hadi ${ }^{1}$ \\ ${ }^{1}$ Pusat Penelitian Oseanografi - LIPI, Jl. Pasir Putih I Ancol Timur, Jakarta 14430, Indonesia \\ ${ }^{2}$ Balai Penelitian Perikanan Laut - KKP, Jl. Raya Jakarta Bogor, Cibinong, Jawa Barat, Indonesia \\ Teregistrasi I tanggal: 25 Agustus 2019; Diterima setelah perbaikan tanggal: 27 April 2020; \\ Disetujui terbit tanggal: 04 Mei 2020
}

\begin{abstract}
ABSTRAK
Perairan karang Taman Nasional Komodo merupakan wilayah penangkapan ikan dan daerah tujuan wisata laut. Kondisi tutupan karang pada umumnya sudah di bawah $50 \%$, namun dampak yang akan muncul terhadap ikan karang belum diteliti dan hal ini dibutuhkan bagi pengelolaan kawasan tersebut. Tujuan penelitian adalah mendapatkan karakteristik struktur komunitas ikan karang, meliputi komposisi, sebaran, kepadatan stok, dan biomassa ikan. Penelitian dilakukan pada bulan Juni 2019 dengan mengunakan metode sensus bawah air pada transek garis permanen untuk masing-masing stasiun penelitian. Sensus visual mendapatkan 128 spesies ikan target dari 21 suku dan 30 spesies ikan indikator dari suku Chaetodontidae. Rata-rata kepadatan stok ikan target dan ikan indikator adalah masing-masing $182 \pm 67$ individu/350m ${ }^{2}$ dan $35 \pm 15$ individu $/ 350 \mathrm{~m}^{2}$. Ukuran panjang ikan terbanyak antara $15 \mathrm{~cm}-30 \mathrm{~cm}$. Biomassa ikan target sebesar $1.174 \pm 617 \mathrm{~kg} /$ hektar. Ikan karang target dan ikan indikator yang memiliki sebaran luas masing-masing 13 spesies dan 2 spesies. Komposisi kehadiran jenis ikan target di lokasi penelitian hanya $3 \%$ yang berdistribusi sangat tinggi, $7 \%$ berdistribusi tinggi, $18 \%$ berdistribusi sedang, $21 \%$ berdistribusi rendah dan $51 \%$ berdistribusi sangat rendah. Sementara jenis-jenis ikan indikator yang intensitas distribusinya sangat tinggi dan tinggi hanya $7 \%$, dan lainnya tergolong sedang $(23 \%)$, rendah $(40 \%)$ sampai sangat rendah $(23 \%)$. Kondisi sebaran spesies diduga menyebabkan keanekaragaman ikan karang pada keseluruhan lokasi penelitian terhitung tinggi, tetapi rendah untuk masing-masing lokasi penelitian. Semua lokasi di dalam kawasan taman nasional maupun diluar taman diperlukan pemantauan dengan porsi yang sama dan dilakukan secara berkala.
\end{abstract} Kata Kunci: Ikan Karang Target; Ikan Karang Indikator; Struktur Komunitas; Taman Nasional
Komodo

\begin{abstract}
Coral Reef Waters of Komodo National Park are fishing grounds and marine tourism destinations. The last condition of coral cover percentages of the regions have sustained below of $50 \%$, however, their future potential impacts on fishes have not been studied and these will be needed in other to manage the regions. The study aimed to update reef fishes data in terms of some features of a community reef fish structure including composition, distribution, density, and biomass. A study was carried out in June, 2019 by using an underwater census visual at a permanent transect belt in the respective study sites. A total of 128 target fish species were recorded belonging to 21 families and 30 indicator fish species of Cahetodontidae were succesfully identified. The density mean of target and indicator fishes are $182 \pm 67$ individual $/ 350 \mathrm{~m}^{2}$ and $35 \pm 15$ individual $/ 350 \mathrm{~m}^{2}$, respectively. Most of fish sizes ranged from $15 \mathrm{~cm}$ to $30 \mathrm{~cm}$. The biomass mean of target fishes are 1,174 \pm 617 $\mathrm{kg} /$ hectare. Only for 13 species of target fishes that have high distribution in overall the study sites and 2 species of indicator fishes, as well. Composition present of target reef fishes in the distribution area given were in levels of $3 \%$ very high, $7 \%$ high, $18 \%$ fair, $21 \%$ low, and $51 \%$ veri low. Meanwhile,
\end{abstract}

Korespondensi penulis:

ayuningtyas.indrawati@gmail.com

DOI: http://dx.doi.org/10.15578/jppi.26.2.2020.75-92 
those for indicator fishes were in levels of $7 \%$ very high and high, $23 \%$ fair, $40 \%$ low, and $23 \%$ veri low. There was mayor significant diversity of reef fishes for overall study sites, however those was minor for respective study sites. The whole locations weather in-side or out-side of Komodo National Park need the equal portion for priodical monitoring.

\section{Keywords: Target-Reef Fishes; Indicator Reef Fishes; Community Structures; Komodo \\ PENDAHULUAN Nasional Park}

Taman Nasional Komodo terletak di bagian ujung barat dari provinsi Nusa Tenggara Timur, terdiri dari tiga pulau besar yaitu Pulau Komodo, Pulau Rinca dan Pulau Padar serta 26 pulau kecil lainnya. Kawasan ini memiliki luas keseluruhan $1.817 \mathrm{~km}^{2}$, dimana luas area daratan yang dilindungi sekitar $603 \mathrm{~km}^{2}$ dan luas area perlindungan laut sekitar $1.214 \mathrm{~km}^{2}$.

Hasil penelitian Putra et al. (2013) di perairan terumbu karang Taman Nasional Komodo menyatakan bahwa lokasi penelitian yang berada dalam kondisi tutupan karang keras hidup kurang dari $50 \%$. Di beberapa lokasi ditemukan tingginya kemunculan patahan-patahan karang, yang umumnya disebabkan oleh aktifitas fisik seperti penangkapan ikan dengan bom dan peletakan jangkar. Sementara itu, dari kategori biomassa dan kepadatan stok ikan herbivora dan ikan target ekonomis penting, hanya dua lokasi yang memiliki kepadatan stok dan biomassa yang konstan dan 14 lokasi lain menunjukkan biomassa dan kepadatan stok yang tidak merata. Variasi tersebut diakibatkan berbagai faktor seperti arus yang kuat, aktivitas perikanan dan bentuk lifeform substrat terumbu karang itu sendiri.

Fungsi dan manfaat terumbu karang (ecosystem services) sangat beragam dan ancaman pemanfaatnya yang meningkat menyebabkan kelestarian terumbu karang terganggu. Keberadaan terumbu karang di perairan Taman Nasional Komodo diperkirakan terancam bukan saja oleh aktifitas perikanan yang tidak ramah lingkungan, tetapi juga oleh aktifitas wisata bahari dengan wisatawan yang tidak bertanggungjawab (Maeilana, 2017). Kondisi yang mengkhawatirkan seperti itu telah menjadi perhatian UNESCO dengan adanya laporan Media Inggris The Guardian, apalagi setelah dijumpai masalah-masalah sampah dan aktivitas-aktivitas yang merusak (Wismabrata, 2018).

Dari sisi data ikan karang, beberapa indikator untuk keperluan monitoring ditentukan dengan menetapkan kelompok ikan karang target dan ikan indikator (Chaetodontidae), yaitu untuk memudahkan dalam perbandingan berdasarkan skala temporal dan spasial. Suku-suku ikan karang target merupakan ikan ekonomis penting dalam pengelolaan kawasan, tetapi pengusahaan ikan tersebut akan menjadi ancaman pada terumbu karang (English et al., 1994; Giyanto et al., 2014). Dengan memahami bagaimana struktur komunitas ikan tersebut dapat digunakan sebagai indikator pemulihan terumbu karang dari kerusakan (resiliensi) seperti ditemukannya kelompok ikan herbivora yang melimpah. Sebaliknya jika ditemukan kelompok ikan karnivora dan plantivora menunujukkan bahwa pemanfaatannya dilakukan secara intensif (Green \& Bellwood, 2009; Obura \& Grimsdith, 2009). Disamping itu, kelimpahan kelompok ikan indikator merupakan ukuran relatif untuk mengetahui penurunan kesehatan terumbu karang secara umum (Pratchett et al., 2006).

Jumlah dan ukuran ikan karang dapat menjadi petunjuk kesehatan terumbu karang secara menyeluruh. Komunitas ikan dapat menunjukkan adanya tanda-tanda terhadap proses oseanografis yang alami, seperti upwelling dan gangguan pemanfaatan seperti tangkap lebih perikanan, polusi dan dampak terjadi perubahan iklim (NOAA, 2019). Pendalaman pada karakteristik struktur komunitas ikan karang dapat digunakan menjadi bahan kebijakan dalam pengelolaan kawasan Taman Nasional Komodo.

Penelitian ini bertujuan untuk mengungkap karakteristik struktur komunitas ikan karang, meliputi komposisi, sebaran, kepadatan stok, biomassa, dan diharapkan informasi ini dapat digunakan sebagai data dasar untuk menilai dan mengelola terumbu karang di perairan Taman Nasional Komodo.

\section{BAHAN DAN METODE}

Lokasi penelitian meliputi area terumbu karang di bagian dalam perairan karang Taman Nasional Komodo. Penelitian ini dilaksanakan pada Juni 2019. Posisi geografis 12 stasiun penelitian dan wilayah administratif masing-masing dijelaskan pada Lampiran 1. Lokasi titik transek diperlihatkan dalam peta (Lampiran 2). Lokasi stasiun penelitian MKDC 01 dan MKDC 02 terletak di luar kawasan TNK, sedangkan MKDC 03 sampai MKDC 12 terletak dalam kawasan TNK.

Metode sensus visual bawah air (UVC) digunakan untuk pengumpulan data jenis ikan dan jumlah individu ikan (English, 1994). Unit analisis mencakup kelompok ikan target dan ikan indikator (Chetodontidae). Identifikasi spesies menggunakan 
buku panduan bergambar (Kuiter \& Tonozuka, 2001; Allen \& Erdmann, 2012).

Pendekatan yang digunakan dalam menaksir panjang ikan dalam air adalah metode "sticks", yaitu mencoba untuk menaksir panjang totak ikan dari mulai ujung mulut ikan sampai ujung sirip ekor dan jumlah ikan yang tersensus dikelompokan ke dalam panjang $5,10,15,20 \mathrm{~cm}$ dst dengan kelipatan 5 (Wilson \& Green, 2009).

Analisa data meliputi perhitungan beberapa parameter di bawah ini:

1. Keanekaragaman jenis adalah total dari spesies ikan karang yang diamati selama monitoring di suatu lokasi ekosistem terumbu karang.

2. Kepadatan stok ikan adalah jumlah individu seluruh spesies ikan karang per luas area pengamatan atau per luasan yang dikonversi dalam hektar, dimana rata-rata kepadatan (D) per meter persegi dihitung menurut rumus:

$D=\frac{\sum \text { individu }(\text { ikan indikator, ikan target: setiap famili })}{350 \mathrm{~m}^{2}}=X$ individu $/ \mathrm{m}^{2}$

3. Biomassa $(B)$ adalah berat individu ikan target $(W)$ per luas are pengamatan.

$$
B=\frac{W(\text { total setiap famili })}{350 \mathrm{~m}^{2}}
$$

Variable berat tiap individu ikan karang didapatkan dengan mengkonversikan variabel panjang ikan pada fungsi hubungan panjang berat ikan. Hubungan panjang berat adalah berat individu ikan target $(W$ ) sama dengan indeks spesifik spesies (a) dikalikan dengan estimasi panjang total dipangkat indeks spesifik spesies (b). Indeks spesifik spesies $(a, b)$ dan panjang ikan disubsitusikan ke rumus panjang berat $W=a^{*} L^{b}$ untuk mendapatkan data berat ikan (gram). Nilai "a" dan "b" dapat dicari di situs web "fishbase" untuk setiap jenis ikan target Froese \& Pauly (2014).

4. Intensitas sebaran jenis masing-masing ikan, yaitu kehadiran setiap spesies ikan pada tiap-tiap stasiun dibagi dengan jumlah stasiun dan dikali $100 \%$. Kategori intensitas sebaran ikan adalah 0 $20 \%$ tergolong sangat rendah, $20-40 \%$ tergolong rendah, $40-60 \%$ tergolong sedang, $60-80 \%$ tergolong tinggi dan $80-100 \%$ tergolong sangat tinggi.
5. Kelompok ikan Chaetodontidae dalam suatu kawasan atau ekosistem terumbu karang di Indonesia dapat dikategorikan sebagai berikut (Suharti et al., 2014):

keanakeragaman jenis rendah: $\mathrm{H}<10$ jenis keanekaragaman jenis sedang: 10 jenis $\leq \mathrm{H} \leq$ 20 jenis keanekaragaman jenis tinggi: $\quad \mathrm{H}>20$ jenis

\section{HASIL DAN BAHASAN \\ Hasil}

\section{Komposisi Jenis dan Penyebaran}

Taman Nasional Komodo memiliki keanekaragaman ikan karang berupa ikan karang target 128 spesies dan ikan indikator (Chaetodontidae) 30 spesies. Pada masing-masing stasiun dijumpai kurang dari 50 spesies untuk ikan target dan kurang dari 19 spesies untuk ikan indikator (Gambar 1).

Sebaran jenis ikan karang tidak merata pada seluruh lokasi penelitian, dimana jumlah jenis menurut letak stasiun bervariasi cukup tinggi. Stasiun dengan jumlah jenis ikan target yang relatif tinggi dibanding stasiun lainnya adalah KMDC 01 di Pulau Pungu (49 spesies) dan KMDC 04 di Gili Lawang (49 spesies). Stasiun dengan jumlah jenis terendah adalah KMDC 08 di Lokima (22 spesies) dan KMDC 11 di Pulau Gaduh (23 spesies). Stasiun penelitian yang memiliki jumlah jenis ikan indikator tertinggi adalah KMDC 07 (19 spesies) dan terendah ditemukan pada stasiun KMDC 06 (4 spesies).

Ditemukan 13 spesies ikan target yang menyebar cukup luas di area penelitian, dimana intensitas sebaran mulai dari kategori sangat tinggi (83 - 92\%) sampai kategori tinggi (67-75\%) berdasarkan jumlah stasiun. Jenis-jenis tersebut adalah Cheilinus fasciatus, Scarus flavipectoralis, Ctenochaetus striatus, Chlorurus sordidus, Scolopsis margaritifer, Hemigymnus melapterus, Scarus dimidiatus, Ctenochaetus binotatus, Pentapodus trivittatus, Parupeneus multifasciatus, Chlorurus bleekeri, Acanthurus auranticavus dan Zebrasoma scopas. Dari 128 spesies yang tersensus, hanya 3\% yang berdistribusi sangat tinggi, 7\% berdistribusi tinggi, 18\% berdistribusi sedang, $21 \%$ berdistribusi rendah dan $51 \%$ berdistribusi sangat rendah (Tabel 1 ). 


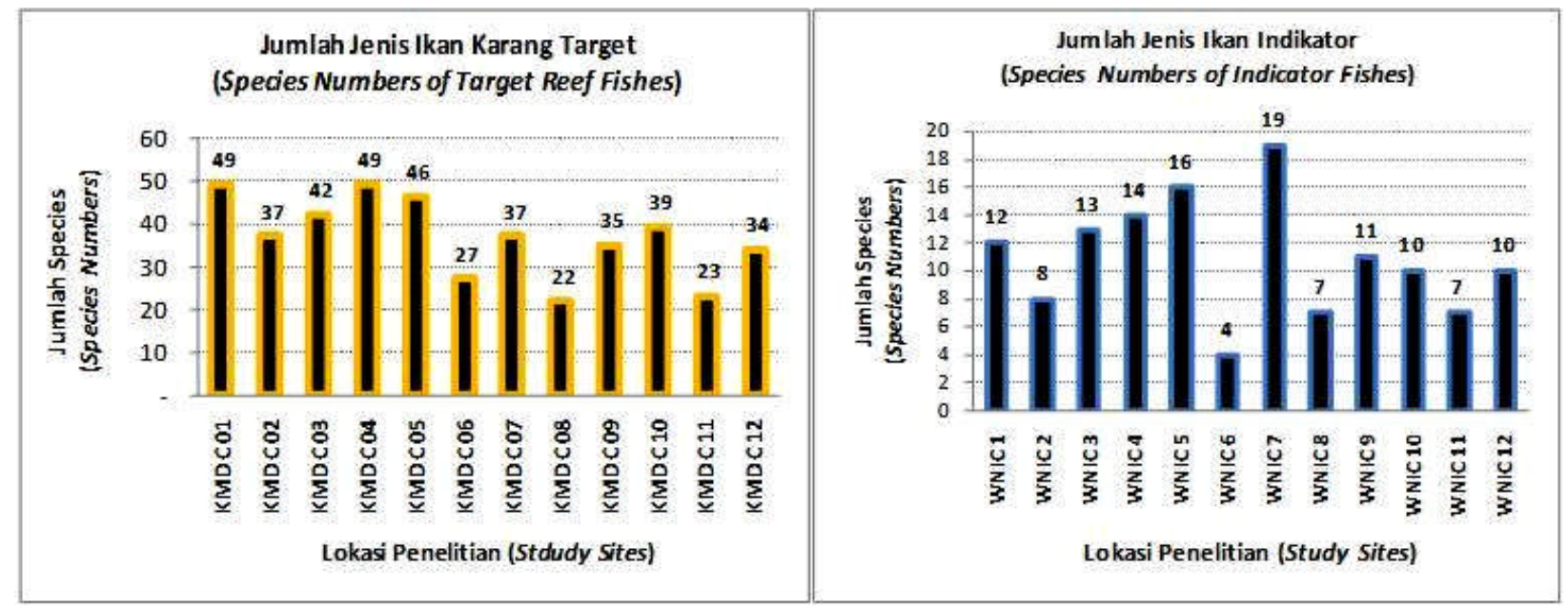

Gambar 1. Variasi jumlah jenis ikan karang target (kiri) dan ikan indikator (kanan) menurut lokasi stasiun di penelitian di Taman Nasional Komodo.

Figure 1. Variation of species numbers of tagret reef fishes (left) and indicator fishes by the study sites in Komodo National Park.

Tabel 1. Intensitas sebaran ikan karang target menurut spesies di Taman Nasional Komodo

Table 1. Distribution intensity of target reef fishes by species in Komodo National Park

\begin{tabular}{|c|c|c|c|c|}
\hline No. & SUKU / Families & JENIS / SPECIES & 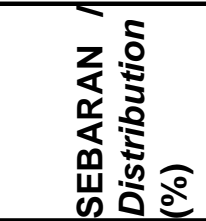 & $\begin{array}{l}\text { INTENSITAS SEBARAN / } \\
\text { Distribution Intensity }\end{array}$ \\
\hline 1 & HEMISCYLLIDAE & Chiloscyllium hasseltii & 8 & Sangat rendah \\
\hline 2 & DASYATIDAE & Taeniura lymma & 33 & Rendah \\
\hline 3 & HOLOCENTRIDAE & Myripristis violacea & 42 & Sedang \\
\hline 4 & & Neoniphon sammara & 25 & Rendah \\
\hline 5 & & Sargocentron rubrum & 8 & Sangat rendah \\
\hline 6 & SERRANIDAE & Aethaloperca rogaa & 17 & Sangat rendah \\
\hline 7 & & Cephalopholis argus & 17 & Sangat rendah \\
\hline 8 & & $\begin{array}{l}\text { Cephalopholis boenak } \\
\text { Cephalopholis }\end{array}$ & 17 & Sangat rendah \\
\hline 9 & & cyanostigma & 58 & Sedang \\
\hline 10 & & Cephalopholis miniata & 8 & Sangat rendah \\
\hline 11 & & Cromileptes altivelis & 25 & Rendah \\
\hline 12 & & Diploprion bifasciatum & 25 & Rendah \\
\hline 13 & & Epinephelus aerolatus & 8 & Sangat rendah \\
\hline 14 & & Epinephelus fasciatus & 25 & Rendah \\
\hline 15 & & Epinephelus maculatus & 17 & Sangat rendah \\
\hline 16 & & Epinephelus merra & 17 & Sangat rendah \\
\hline 17 & & Epinephelus ongus & 8 & Sangat rendah \\
\hline 18 & & Plectropomus aerolatus & 8 & Sangat rendah \\
\hline 19 & & $\begin{array}{l}\text { Plectropomus maculatus } \\
\text { Plectropomus }\end{array}$ & 42 & Sedang \\
\hline 20 & & oligocanthus & 17 & Sangat rendah \\
\hline 21 & PRIACANTHIDAE & Priacanthus hamrur & 8 & Sangat rendah \\
\hline 22 & SCOLOPSIDAE & Scolopsis affinis & 8 & Sangat rendah \\
\hline 23 & & Scolopsis bilineatus & 50 & Sedang \\
\hline 24 & & Scolopsis ciliatus & 17 & Sangat rendah \\
\hline 25 & & Scolopsis lineatus & 33 & Rendah \\
\hline 26 & & Scolopsis margaritifer & 75 & Tinggi \\
\hline 27 & & Scolopsis monogramma & 8 & Sangat rendah \\
\hline
\end{tabular}




\begin{tabular}{|c|c|c|c|c|}
\hline 28 & NEMIPTERIDAE & Pentapodus caninus & 42 & Sedang \\
\hline 29 & & Pentapodus emeryi & 17 & Sangat rendah \\
\hline 30 & & Pentapodus trivittatus & 67 & Tinggi \\
\hline 31 & HAEMULIDAE & $\begin{array}{l}\text { Diagramma maculatum } \\
\text { Plectorhinchus }\end{array}$ & 8 & Sangat rendah \\
\hline 32 & & chaetodontoides & 8 & Sangat rendah \\
\hline 33 & & Plectorhinchus lessonii & 33 & Rendah \\
\hline 34 & & $\begin{array}{l}\text { Plectorhinchus lineata } \\
\text { Plectorhinchus }\end{array}$ & 17 & Sangat rendah \\
\hline 35 & & polytaenia & 8 & Sangat rendah \\
\hline 36 & & Plectorhinchus vittatus & 42 & Sedang \\
\hline 37 & LUTJANIDAE & Lutjanus biguttatus & 17 & Sangat rendah \\
\hline 38 & & Lutjanus bohar & 25 & Rendah \\
\hline 39 & & Lutjanus carponotatus & 17 & Sangat rendah \\
\hline 40 & & Lutjanus decussatus & 42 & Sedang \\
\hline 41 & & Lutjanus fulviflamma & 17 & Sangat rendah \\
\hline 42 & & Lutjanus gibbus & 17 & Sangat rendah \\
\hline 43 & & Lutjanus monostigma & 17 & Sangat rendah \\
\hline 44 & & Lutjanus quinquelineatus & 8 & Sangat rendah \\
\hline 45 & & Lutjanus fulvus & 25 & Rendah \\
\hline 46 & & Macolor macularis & 25 & Rendah \\
\hline 47 & CAESIONIDAE & Caesio caerulaurea & 33 & Rendah \\
\hline 48 & & Caesio cuning & 25 & Rendah \\
\hline 49 & & Caesio lunaris & 8 & Sangat rendah \\
\hline 50 & & Pterocaesio chrysozona & 8 & Sangat rendah \\
\hline 51 & & Pterocaesio diagramma & 25 & Rendah \\
\hline 52 & & Pterocaesio pisang & 33 & Rendah \\
\hline 53 & & Pterocaesio tile & 33 & Rendah \\
\hline 54 & & Pterocaesio trilineata & 8 & Sangat rendah \\
\hline 55 & LETHRINIDAE & Lethrinus erythropterus & 25 & Rendah \\
\hline 56 & & Lethrinus obsoletus & 8 & Sangat rendah \\
\hline 57 & & Lethrinus ornatus & 17 & Sangat rendah \\
\hline 58 & & $\begin{array}{l}\text { Monotaxis grandoculis } \\
\text { Mulloidichthys }\end{array}$ & 50 & Sedang \\
\hline 59 & MULLIDAE & $\begin{array}{l}\text { flavolineatus. } \\
\text { Mulloidichthys }\end{array}$ & 8 & Sangat rendah \\
\hline 60 & & $\begin{array}{l}\text { vanicolensis } \\
\text { Parupeneus }\end{array}$ & 8 & Sangat rendah \\
\hline 61 & & barberinoides & 25 & Rendah \\
\hline 62 & & $\begin{array}{l}\text { Parupeneus barberinus } \\
\text { Parupeneus }\end{array}$ & 58 & Sedang \\
\hline 63 & & $\begin{array}{l}\text { cyclostomus } \\
\text { Parupeneus }\end{array}$ & 17 & Sangat rendah \\
\hline 64 & & multifasciatus & 67 & Tinggi \\
\hline 65 & & Upeneus tragula & 8 & Sangat rendah \\
\hline 66 & EPHIPPIDAE & Platax teira & 8 & Sangat rendah \\
\hline 67 & POMACANTHIDAE & $\begin{array}{l}\text { Pomacanthus imperator } \\
\text { Pomacanthus }\end{array}$ & 8 & Sangat rendah \\
\hline 68 & & $\begin{array}{l}\text { semicircularis } \\
\text { Pomacanthus }\end{array}$ & 8 & Sangat rendah \\
\hline 69 & & sexstriatus & 25 & Rendah \\
\hline 70 & & Pygoplites diancanthus & 17 & Sangat rendah \\
\hline 71 & LABRIDAE & Cheilinus bimaculatus & 50 & Sedang \\
\hline 72 & & Cheilinus celebicus & 8 & Sangat rendah \\
\hline 73 & & Cheilinus fasciatus & 92 & Sangat Tinggi \\
\hline 74 & & Cheilinus trilobatus & 58 & Sedang \\
\hline 75 & & Cheilinus undulatus & 25 & Rendah \\
\hline
\end{tabular}




\begin{tabular}{|c|c|c|c|c|}
\hline 76 & & $\begin{array}{l}\text { Choerodon anchorago } \\
\text { Choerodon }\end{array}$ & 50 & Sedang \\
\hline 77 & & zosterophorus & 25 & Rendah \\
\hline 78 & & Epibulus insidator & 42 & Sedang \\
\hline 79 & & Hemigymnus fasciatus & 58 & Sedang \\
\hline 80 & & Hemigymnus melapterus & 75 & Tinggi \\
\hline 81 & & $\begin{array}{l}\text { Oxycheilinus digramma } \\
\text { Bolbometopon }\end{array}$ & 50 & Sedang \\
\hline 82 & SCARIDAE & muricatum & 17 & Sangat rendah \\
\hline 83 & & Cetoscarus bicolor & 25 & Rendah \\
\hline 84 & & Chlorurus bleekeri & 67 & Tinggi \\
\hline 85 & & Chlorurus sordidus & 83 & Sangat Tinggi \\
\hline 86 & & Hipposcarus longiceps & 8 & Sangat rendah \\
\hline 87 & & Scarus capistratoides & 8 & Sangat rendah \\
\hline 88 & SCARIDAE & Scarus cemelon & 17 & Sangat rendah \\
\hline 89 & & Scarus dimidiatus & 75 & Tinggi \\
\hline 90 & & Scarus flavipectoralis & 92 & Sangat Tinggi \\
\hline 91 & & Scarus forsteni & 17 & Sangat rendah \\
\hline 92 & & Scarus ghobban & 58 & Sedang \\
\hline 93 & & Scarus niger & 42 & Sedang \\
\hline 94 & & Scarus quoyi & 42 & Sedang \\
\hline 95 & & Scarus psitacus & 25 & Rendah \\
\hline 96 & & Scarus rivulatus & 8 & Sangat rendah \\
\hline 97 & & Scarus schlegeli & 17 & Sangat rendah \\
\hline 98 & SIGANIDAE & Siganus canaliculatus & 8 & Sangat rendah \\
\hline 99 & & Siganus corallinus & 17 & Sangat rendah \\
\hline 100 & & Siganus doliatus & 17 & Sangat rendah \\
\hline 101 & & Siganus puellus & 42 & Sedang \\
\hline 102 & & Siganus punctatissimus & 33 & Rendah \\
\hline 103 & & Siganus virgatus & 17 & Sangat rendah \\
\hline 104 & & Siganus vulpinus & 58 & Sedang \\
\hline 105 & ACANTHURIDAE & Acanthurus auranticavus & 67 & Tinggi \\
\hline 106 & & Acanthurus leucocheilus & 8 & Sangat rendah \\
\hline 107 & & Acanthurus lineatus & 17 & Sangat rendah \\
\hline 108 & & Acanthurus mata & 8 & Sangat rendah \\
\hline 109 & & Acanthurus nigricans & 8 & Sangat rendah \\
\hline 110 & & Acanthurus nigrofuscus & 25 & Rendah \\
\hline 111 & & Acanthurus nubilus & 17 & Sangat rendah \\
\hline 112 & & Acanthurus olivaceus & 25 & Rendah \\
\hline 113 & & Acanthurus pyroferus & 42 & Sedang \\
\hline 114 & & Acanthurus thompsoni & 8 & Sangat rendah \\
\hline 115 & & $\begin{array}{l}\text { Ctenochaetus binotatus } \\
\text { Ctenochaetus }\end{array}$ & 75 & Tinggi \\
\hline 116 & & cyanocheilus & 17 & Sangat rendah \\
\hline 117 & & Ctenochaetus striatus & 92 & Sangat Tinggi \\
\hline 118 & & Naso brevirostris & 33 & Rendah \\
\hline 119 & & Naso hexacanthus & 33 & Rendah \\
\hline 120 & & Naso lituratus & 33 & Rendah \\
\hline 121 & & Naso lopezi & 8 & Sangat rendah \\
\hline 122 & & Naso unicornis & 8 & Sangat rendah \\
\hline 123 & & Naso vlamingii & 58 & Sedang \\
\hline 124 & & Zebrasoma scopas & 67 & Tinggi \\
\hline 125 & BALISTIDAE & Balistapus undulatus & 58 & Sedang \\
\hline 126 & & Balistoides viridescens & 42 & Sedang \\
\hline 127 & SCOMBRIDAE & Megalaspis cordyla & 8 & Sangat rendah \\
\hline 128 & CARANGIDAE & Caranx sexfasciatus & 8 & Sangat rendah \\
\hline
\end{tabular}


Sementara jenis ikan indikator yang intensitas distribusinya sangat tinggi (92 - 100\%) dan tinggi $(67$ $-75 \%$ ) masing-masing hanya 2 spesies ( $7 \%$ dari 30 jenis yang tersensus), yaitu Chaetodon kleinii,
Chaetodon lunulatus, Chaetodon melannotus, dan Heniochus varius (Tabel 2). Jenis ikan indikator lainnya tergolong sedang $(23 \%)$, rendah $(40 \%)$ sampai sangat rendah $(23 \%)$.

Tabel 2. Intensitas sebaran ikan karang indikator menurut spesies di Taman Nasional Komodo Table 2. Distribution intensity of Indicator reef fishes by species in Komodo National Park

\begin{tabular}{|c|c|c|c|c|c|c|c|}
\hline No & JENIS / Species & 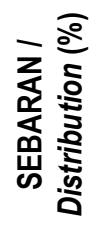 & $\begin{array}{c}\text { INTENSITAS } \\
\text { SEBARAN / } \\
\text { Distribution } \\
\text { Intensity }\end{array}$ & No & JENIS / Species & 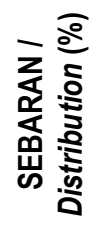 & $\begin{array}{l}\text { INTENSITAS } \\
\text { SEBARAN / } \\
\text { Distribution } \\
\text { Intensity }\end{array}$ \\
\hline 1 & Chaetodon kleinii & 100 & Sangat tinggi & 16 & Chaetodon & 33 & Rendah \\
\hline 2 & Chaetodon Iunulatus & 92 & Sangat tinggi & 17 & Chaetodon xanthurus & 33 & Rendah \\
\hline 3 & Chaetodon melannotus & 75 & Tinggi & 18 & Chelmon rostratus & 33 & Rendah \\
\hline 4 & Heniochus varius & 67 & Tinggi & 19 & Heniochus chrysostomus & 33 & Rendah \\
\hline 5 & Chaetodon baronessa & 58 & Sedang & 20 & Chaetodon bennetti & 25 & Rendah \\
\hline 6 & Chaetodon speculum & 58 & Sedang & 21 & Chaetodon ephippium & 25 & Rendah \\
\hline 7 & Chaetodon trifascialis & 50 & Sedang & 22 & Chaetodon rafflesii & 25 & Rendah \\
\hline 8 & Coradion altivelis & 50 & Sedang & 23 & Parachaetodon ocellatus & 25 & Rendah \\
\hline 9 & Chaetodon Iunula & 42 & Sedang & 24 & Chaetodon punctatofasciatus & 17 & Sangat rendah \\
\hline 10 & Chaetodon octofasciatus & 42 & Sedang & 25 & Forcipiger flavissimus & 17 & Sangat rendah \\
\hline 11 & Chaetodon vagabundus & 42 & Sedang & 26 & Chaetodon decussatus & 8 & Sangat rendah \\
\hline 12 & Chaetodon adiergastos & 33 & Rendah & 27 & Chaetodon semeion & 8 & Sangat rendah \\
\hline 13 & Chaetodon auriga & 33 & Rendah & 28 & Hemitaurichthys polylepis & 8 & Sangat rendah \\
\hline 14 & Chaetodon lineolatus & 33 & Rendah & 29 & Heniochus dephreutus & 8 & Sangat rendah \\
\hline 15 & Chaetodon ocellicaudus & 33 & Rendah & 30 & Heniochus singularis & 8 & Sangat rendah \\
\hline
\end{tabular}

Komposisi jenis ikan karang target (Tabel 3) menurut besarnya jumlah individu dari lima belas jenis dominan tertinggi (antara $2 \%-6 \%$ ) berturut-turut diwakili oleh jenis Pterocaesio pisang, Caesio caerulaurea, Ctenochaetus striatus, Scarus flavipectoralis, Pterocaesio diagramma, Myripristis violacea, Ctenochaetus binotatus, Pterocaesio trilineata, Chlorurus sordidus, Neoniphon sammara, Pterocaesio tile, Chlorurus bleekeri, Acanthurus auranticavus dan Caesio cuning.

Komposisi berdasarkan biomassa untuk lima belas jenis ikan karang target yang relatif besar sumbangannya adalah berturut-turut diwakili oleh Myripristis violacea, Caesio caerulaurea, Naso vlamingii, Acanthurus auranticavus, Pterocaesio diagramma, Scarus flavipectoralis, Acanthurus mata,
Chlorurus sordidus, Naso hexacanthus, Chlorurus bleekeri, Scolopsis lineatus, Neoniphon sammara, Lutjanus fulvus dan Caesio cuning (Tabel 3). Jenis tersebut menunjukkan bahwa kontribusi biomassa ikan karang ditentukan oleh ikan soliter yang selalu dijumpai dalam jumlah besar atau oleh ikan yang bersifat bergerombol (schooling). Namun jenis tersebut bukan merupakan jenis tangkapan ekonomis penting. Hanya sedikit jenis dengan jumlah individual yang tinggi dan dengan sebaran rendah yang merupakan target tangkapan ekonomis penting, seperti ikan ekor kuning dan pisang-pisang (Caesio spp. dan Pterocaesio spp.), kelompok ikan kuwe (Caranx sexfasciatus). Jenis ikan berharga tinggi namun termasuk ikan rawan punah yang dilindungi regulasi, adalah jenis ikan Napoleon (Cheilinus undulatus), yang dijumpai beberapa ekor pada tiga stasiun penelitian (KMDC 03, 05 dan 07). 


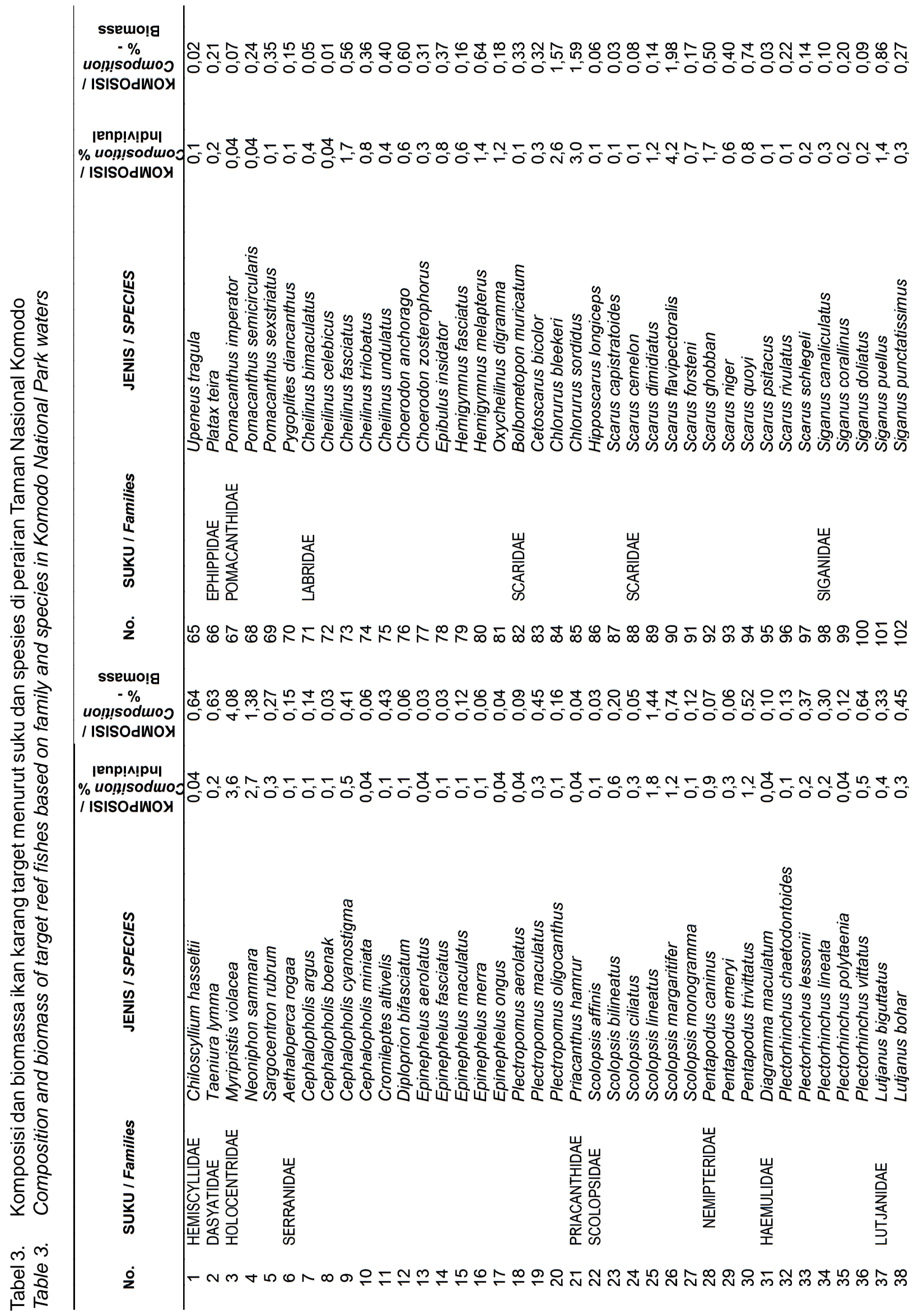




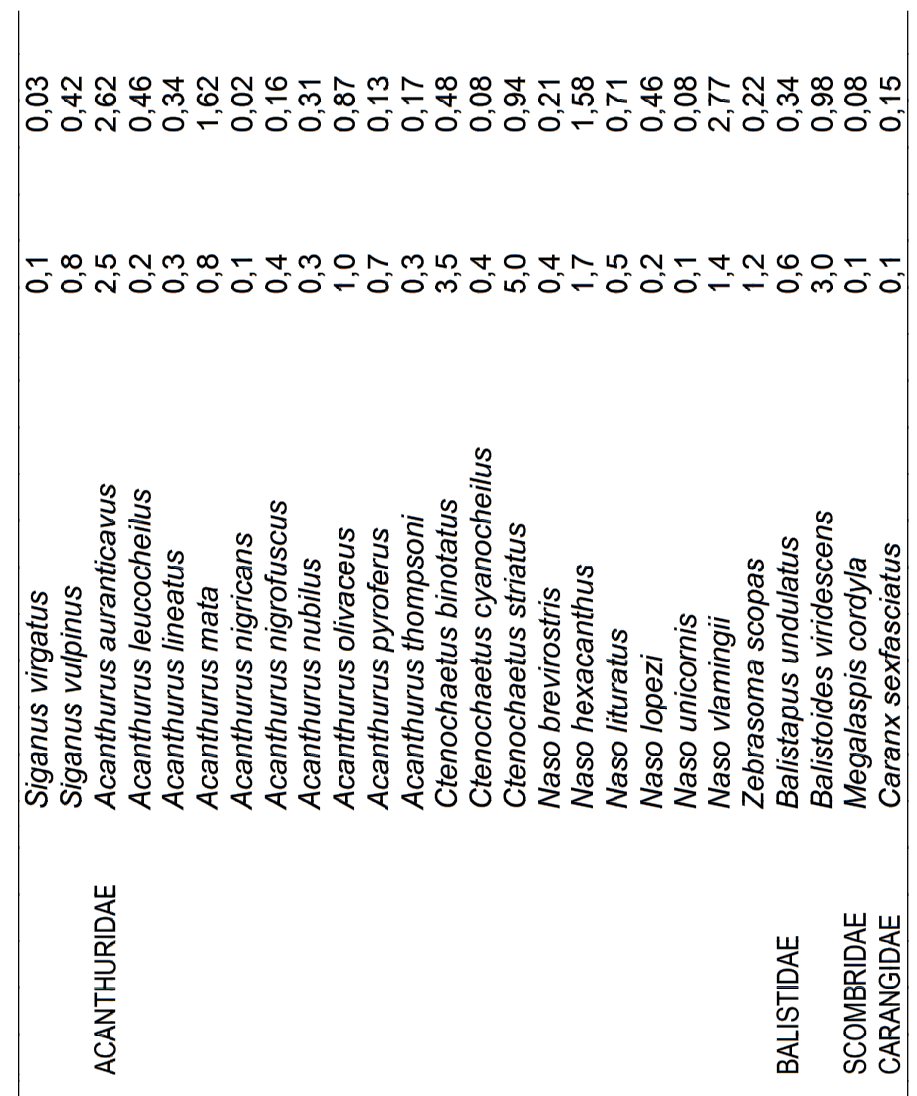

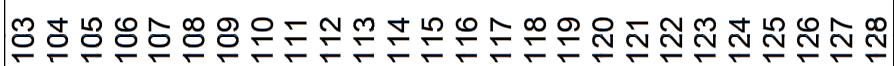

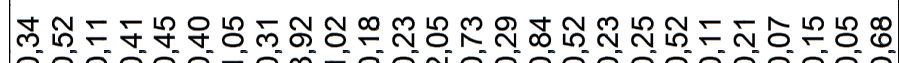

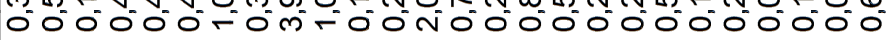

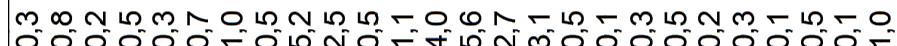
O O. O.
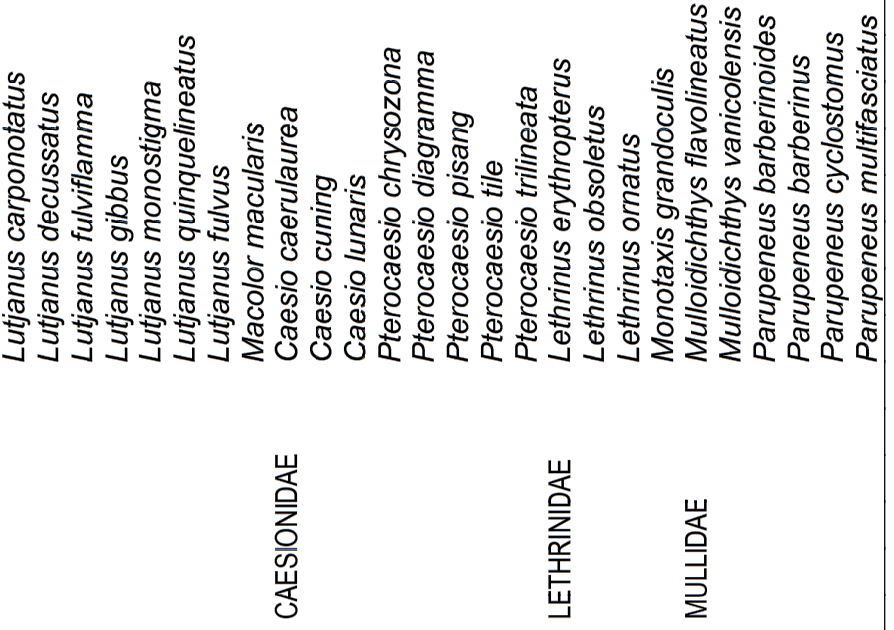

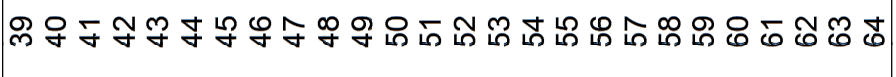


Komposisi jenis ikan indikator dari suku Chaetodontidae (Gambar 2) diwakili oleh 10 spesies secara berurutan, yaitu Chaetodon kleinii, Chaetodon melannotus, Chaetodon Iunulatus, Chaetodon baronessa, Chaetodon octofasciatus, Heniochus varius, Chaetodon ocellicaudus, Chaetodon trifascialis, Chaetodon lineolatus, dan Chaetodon speculum.

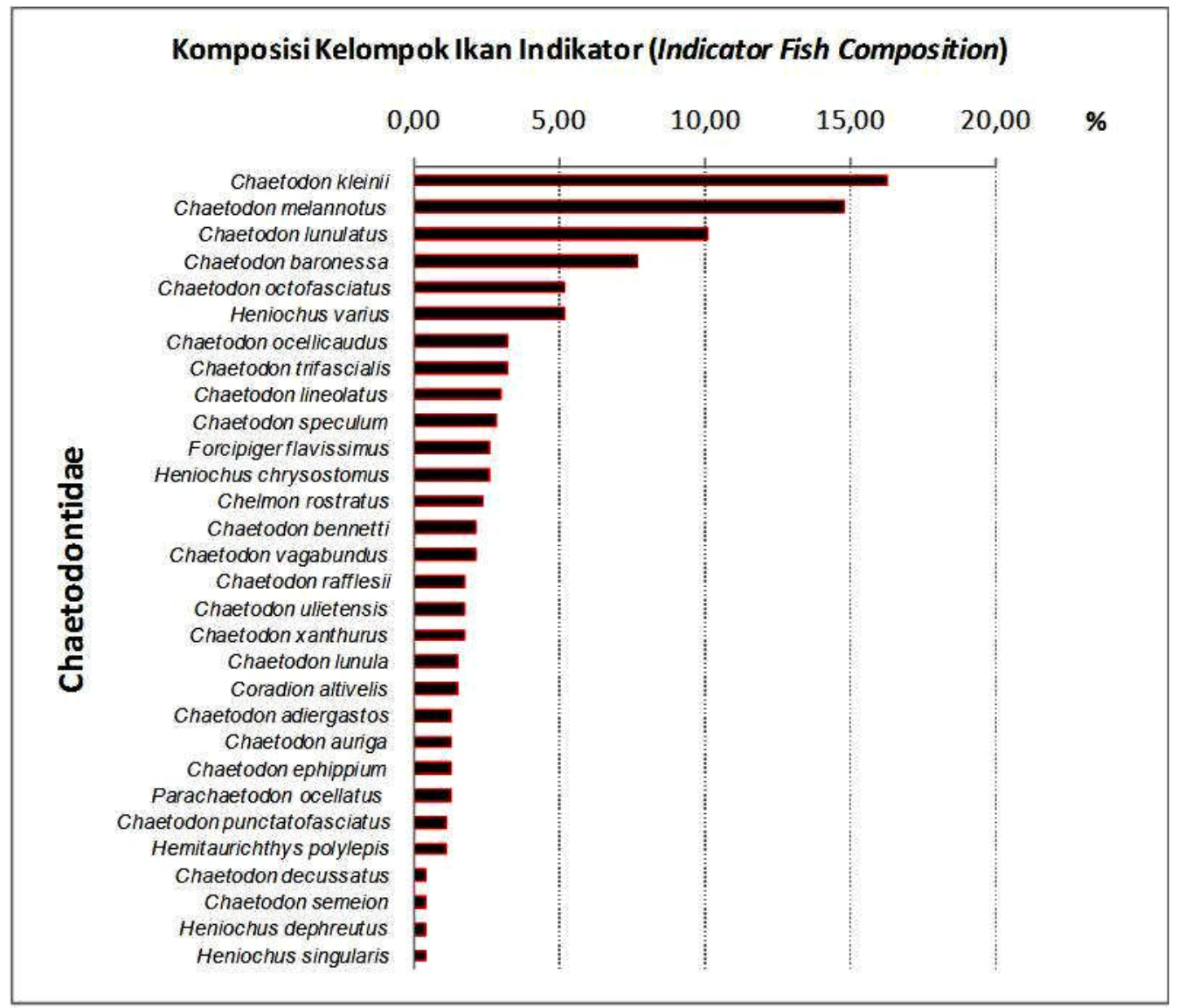

Gambar 2. Komposisi ikan karang indikator (\%) menurut spesies.

Figure 2. Composition of reef fish indicators (\%) by species.

\section{Kepadatan Stok Ikan}

Rata-rata jumlah individu ikan karang target adalah $182 \pm 67$ ekor / transek $350 \mathrm{~m}^{2}$ atau setara dengan $0,52 \pm 0,2 \mathrm{ekor} / \mathrm{m}^{2}$ dan rata-rata jumlah individu sebesar $5.195 \pm 1.880$ ekor/hektar. Simpangan baku dari kepadatan stok ini cukup besar, karena adanya variasi kepadatan stok yang terlampau lebar (Gambar 3). Kepadatan stok tertinggi sebesar 323 ekor/350 $\mathrm{m}^{2}$ yang dijumpai pada stasiun KMDC 05 (Gili Kelor) dan kepadatan stok terendah dijumpai pada stasiun KMDC 11 di Pulau Gaduh sebesar 52 ekor/350m².

Rata-rata kepadatan stok kelompok ikan indikator dari suku Chaetodontidae adalah $35 \pm 15$ ekor/350 $\mathrm{m}^{2}$, dengan simpangan baku kepadatan stok masih cukup tinggi. Kepadatan stok ikan indikator yang tertinggi dijumpai pada stasiun KMDC 07 (104 ekor/ $350 \mathrm{~m}^{2}$ ) dan kepadatan stok terendah dijumpai pada stasiun KMDC 08 (16 ekor/350m²). Variasi kepadatan stok pada masing-masing stasiun diilustrasikan pada Gambar 4. 


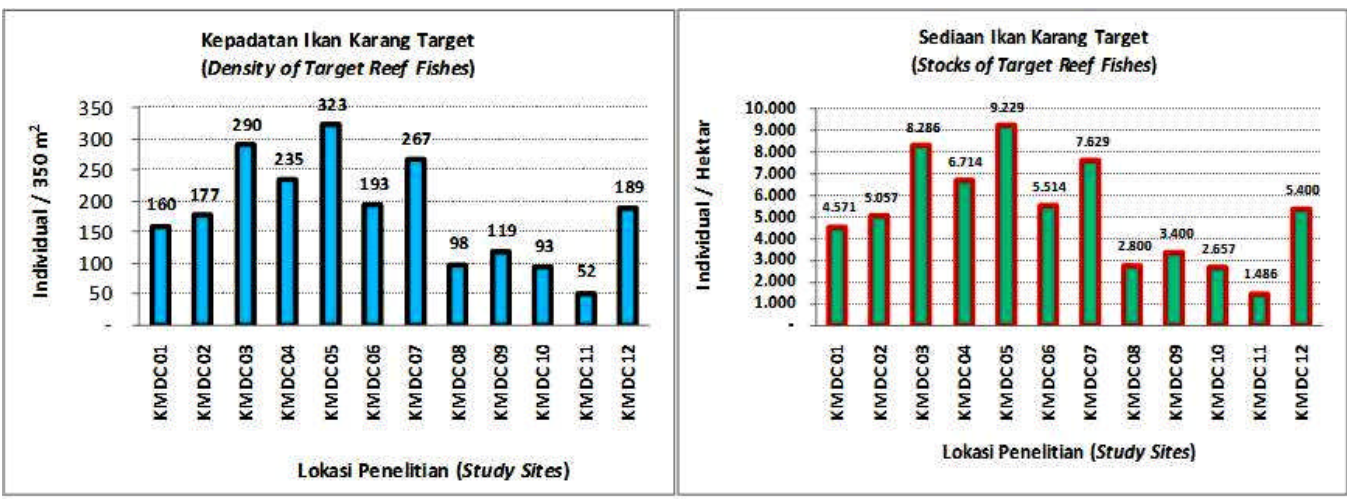

Gambar 3. Kepadatan dan sediaan ikan karang berdasarkan lokasi penelitian.

Figure 3. Density and stocks of target reef fishes based on study sites.

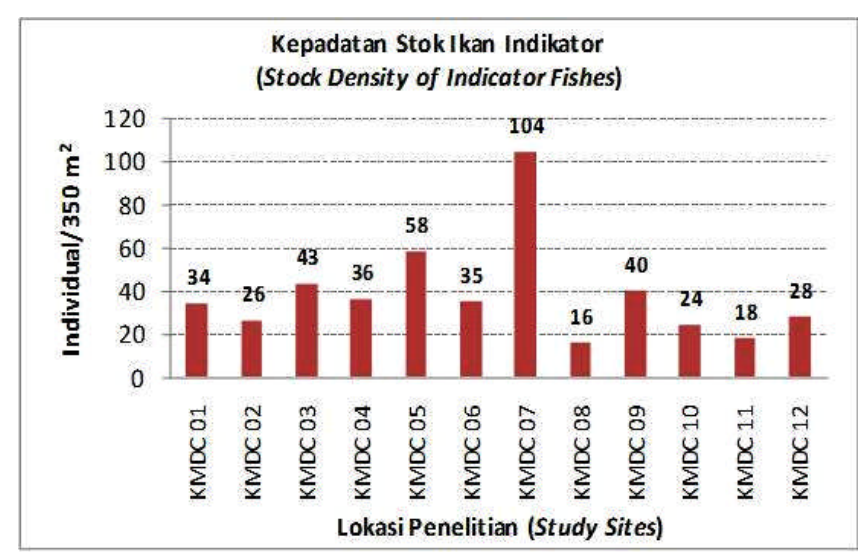

Gambar 4. Kepadatan stok ikan indikator berdasarkan lokasi stasiun penelitian.

Figure 4. Stock densities indicator reef fish based on study sites.

\section{Biomassa}

Hasil analisa data mendapatkan rata-rata biomassa ikan karang target sebesar $41.089 \pm 21.605 \mathrm{gr} / 350$ $\mathrm{m} 2$ atau jika dikonversi setara dengan $1.174 \pm 617$ $\mathrm{kg} / \mathrm{hektar}$. Simpangan baku dari rata-rata tersebut sangat tinggi, karena terdapat variasi biomassa yang sangat lebar antara stasiun penelitian. Biomassa tertinggi dari ikan karang target dijumpai erturut-turut pada stasiun KMDC 07, KMDC 05, KMDC 01 dan
KMDC 03, yaitu dengan sediaan berkisar antara 1,8 ton hingga 2,1 ton/hektar. Sebaliknya biomassa terendah dijumpai pada stasiun KMDC 08 dan KMDC 11 , yaitu dengan sediaan antara 0,3 ton sampai 0,5 ton/hektar (Gambar 5). Penyumbang biomassa tertinggi untuk ikan karang target (Tabel 1 ) adalah dari kelompok ikan butana (Acanthuridae), ekor kuning dan pisang-pisang (Caesionidae) serta ikan kakatua (Scaridae). Biomasa ikan bergantung pada sebaran ukuran panjang ikan dan jumlah ikan. (Gambar 6).

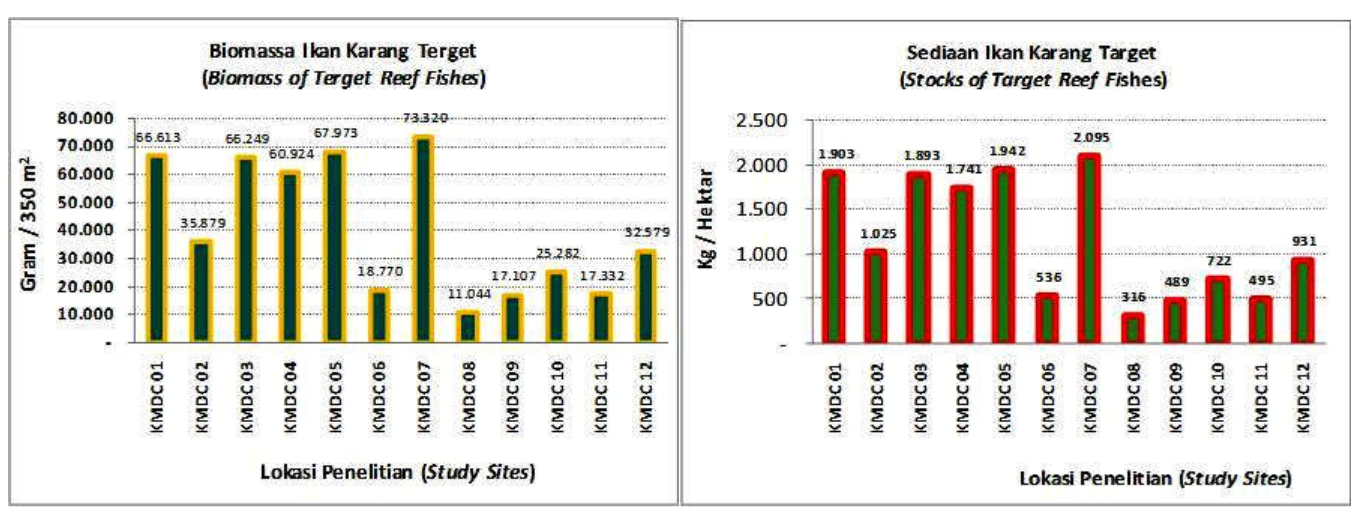

Gambar 5. Variasi biomassa ikan karang target menurut lokasi penelitian.

Figure 5. Biomass variation of target reef fishes by study sites. 


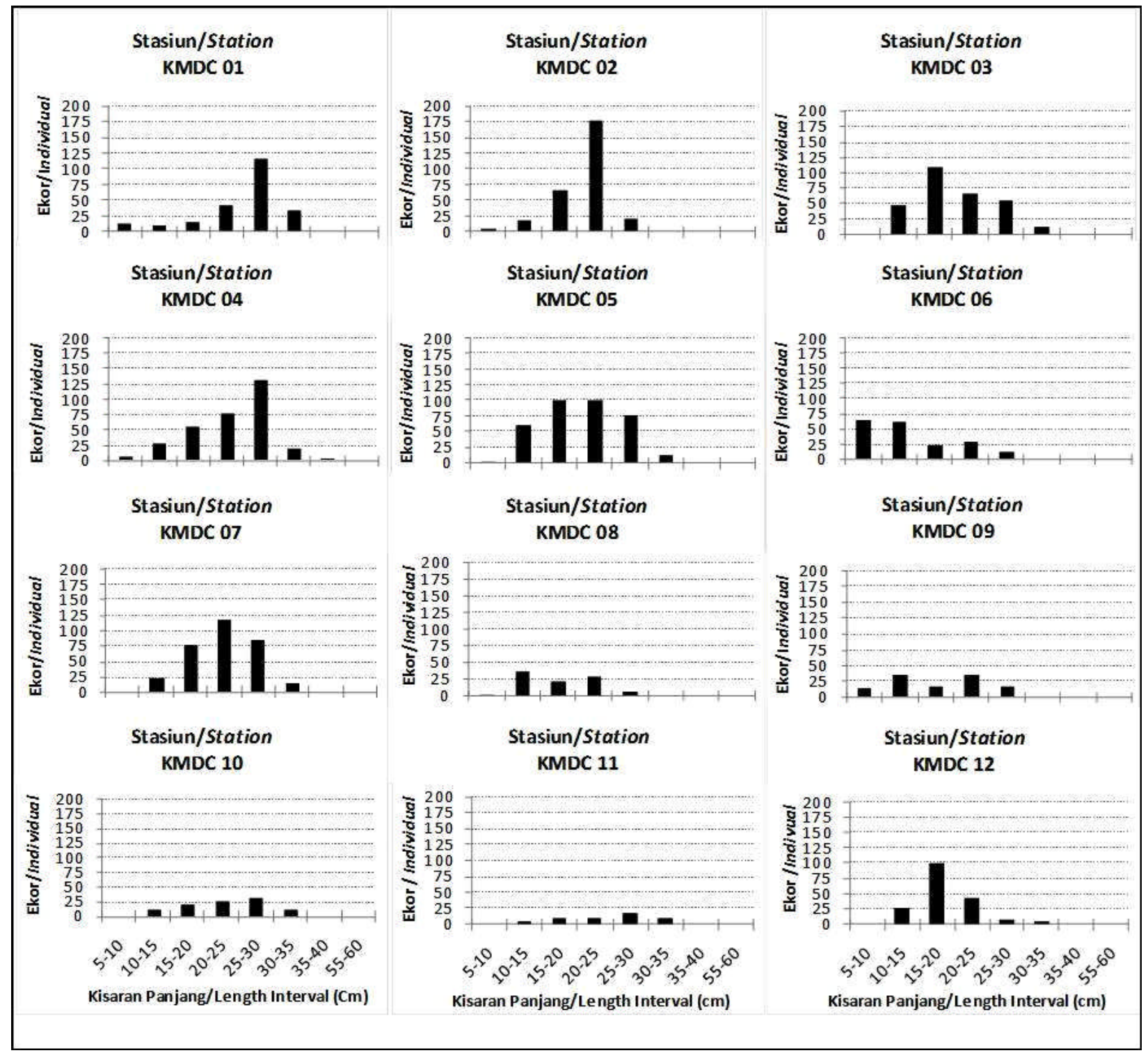

Gambar 6. Sebaran panjang ikan menurut jumlah individu dan statiun penelitian.

Figure 6. Length distribution by individual numbers and research station.

Jumlah individu ikan terbanyak tersebar pada ukuran interval 15 sampai $30 \mathrm{~cm}$ yang ditemukan pada stasiun KMDC 01, 02, 03, 04, 05 dan 07 dengan konversi biomassa ikan dalam satuan hektar pada stasiun-stasiun tersebut berkisar pada 1 ton/ha sampai 1,9 ton/ha. Sebaliknya stasiun KMDC 06 dijumpai banyak ikan dengan ukuran interval $5-10$ $\mathrm{cm}$ yang merupakan ikan berukuran kecil, sehingga biomassa di stasiun tersebut rendah. Stasiun lainnya seperti KMDC 08, 09, 10, 11 dan 12 memiliki sebaran ukuran interval panjang cukup bervariasi antara 5-10 $\mathrm{cm}$ sampai $30-35 \mathrm{~cm}$, tetapi memiliki jumlah individu yang rendah di semua stasiun tersebut, sehingga biomassa ikan menjadi rendah.

\section{Bahasan}

Hasil sensus visual ikan karang ini menunjukkan bahwa keanekaragaman ikan karang cukup tinggi jika berpatokan pada seluruh kawasan Taman Nasional Komodo, namun dalam hitungan area yang lebih sempit atau mengacu pada area terbatas (lokasi ransek) di masing-masing lokasi atau antara pulau ke pulau memiliki keragaman jenis yang rendah. Variasi jumlah jenis antara lokasi yang berbeda sangat berbeda satu sama lain. Hal ini disebabkan oleh rendahnya intensitas sebaran masing-masing jenis ikan karang target. Hanya sedikit spesies ikan karang yang memiliki tingkat sebaran cukup luas 
antara $50 \%$ sampai $90 \%$ dari jumlah stasiun penelitian. Hal ini merupakan fenomena yang umum dijumpai, seperti di banyak lokasi penelitian kesehatan terumbu karang (Edrus \& Hadi, 2019; Edrus \& Suharti, 2016; Suharti \& Edrus, 2016). Kondisi seperti ini hampir sama dengan temuan dari penelitian Putra et al. (2013) pada kawasan yang sama. Putra et al. (2013) menyebutkan bahwa kondisi seperti ini disebabkan oleh faktor arus yang kuat, aktivitas perikanan dan perbedaan variasi habitat ikan. Disamping itu, keanekaragaman spesies ikan karang yang berbeda dari suatu area perairan karang ke area karang yang lainnya pada suatu kawasan akan membentuk variasi-variasi dalam hal jumlah jenis, komposisi dan biomassa ikan karang (Luckhurst \& Luckhurst 1978; Carpenter et al., 1981), namun tidak selalu berhubungan dengan jumlah individual (Carpenter et al., 1981). Keanekaragaman dan variasi-variasi tersebut disebabkan oleh kompleksitas dan relief dari substrat terumbu. Kompleksitas seperti itu dibentuk oleh kehidupan bentik karang dan banyaknya mikro habitat, dimana fungsi ikan ditentukan dalam perannya pada mikro habitat tersebut dan kehadiran ikan sering dikaitkan dengan tutupan karang keras (Roberts \& Ormond 1987; Feary et al., 2007). Penilaian atas tutupan karang batu dan kompleksitas tersebut bagi kehadiran ikan tidaklah mudah, karena perubahan kualitas kecerahan kolom air juga berpengaruh terhadap respon ikan, meskipun tutupan karang batu tergolong tinggi (Amesbury 1981; Edrus \& Setyawan 2013). Komposisi kehadiran jenis ikan pada masingmasing tempat penelitian dapat disebabkan oleh perbedaan kompleksitas tersebut, dimana perubahan pada kompleksitas substrat terumbu akan berakibat pada berubahnya struktur komunitas ikan karang (Roberts \& Ormond, 1987). Perbedaan komunitas ikan karang dapat ditemukan sepanjang perubahan relief geografis dan perbedaan tipe karang (Joyeux et al., 2001; Ferreira et al., 2001). Pola komposisi dan sebaran dari kelompok ikan karang yang sering bervariasi lintas ruang dan waktu adalah dipengaruhi oleh satu paket faktor fisik dan biologis yang terintegrasi (Acosta \& Robertson, 2002; Syms \& Jones, 2000;). Keterbukaan terhadap ombak, kedalaman perairan dan kompleksitas topografis dapat menimbulkan tingkat peubah dari intervensi terhadap banyak proses ekologis, seperti rekruitmen, predasi dan teritorial (Cheney \& Côté, 2003; Kawasaki et al., 2003). Hasil penelitian Neto et al. (2018) di Brazil menunujukkan bahwa komunitas ikan karang di dalam zona pantai Itaipu meskipun memperlihatkan struktur yang serupa, tetapi perbedaannya di antara lokasi adalah bukti bahwa umumnya bukan saja berhubungan dengan pola karang batu, tetapi juga oleh faktor-faktor lingkungan yang sangat bervariasi dari satu tempat ke tempat lain dan juga bervariasi sepanjang tahun.

Komposisi jenis ikan target dalam hal jumlah spesies yang ditemukan pada perairan Taman Nasional Komodo teramati lebih rendah pada masingmasing stasiun jika dibandingkan hasil survei kesehatan terumbu karang di lokasi Wakatobi (Tuti et al., 2017; 2018) dan di perain Buton (Hadi et al., 2018), tetapi lebih tinggi jika dibandingkan dengan hasil Reef Health Monitoring di wilayah terumbu karang di perairan Sikka Flores yang termasuk dalam Kawasan Konservasi Perairan Daerah Kabupaten SIKKA (Suharti \& Edrus, 2016).

Dari kondisi keragaman jenis, kelompok ikan brajanata/mata besar (Holocentridae), kerapu (Serranidae), kakap (Lutjanidae), Lencam (Lethrinidae), bibir tebal (Haemulidae), baronang (Siganidae), butana (Acanthuridae), kakatua (Scaridae), labrid (Labridae), biji nangka (Mullidae) dan kurisi pasir (Scolopsidae) merupakan jenis-jenis yang bersifat penetap (major resident), sebagai penghuni sejati liang-liang karang atau kelompok ikan pelintas yang ratusan kali keluar masuk area terumbu karang untuk mencari makan, seperti ikan ekor kuning (Caesio spp.) dan pisang-pisang (Oterocaesio spp.) dari Caesionidae atau dari suku Scombridae seperti kembung (Rastrelliger kanagurta) dan selar Selar boops yang selalu melintas terumbu karang dan bersifat shcooling (Allen \& Erdmann, 2012). Namun fakta lapangan menunjukkan bahwa jenis-jenis dari kelompok ikan tersebut tidak semua jenisnya ditemukan pada keseluruhan lokasi penelitian, karena rugositas atau relief dasar perairan dan substrat karang yang berbeda di antara lokasi yang satu dengan yang lain sebagai pembatas distribusi ikan (Green, 1996; Jones et al., 2004 Mallela et al., 2007) dan tidak semua jenis ikan pelintas dikategorikan sebagai ikan karang, seperti ikan selar (Selar boops) dan ikan kembung (Rastrelliger kanagurta) yang merupakan ikan pelagis yang juga ditemukan di area transek dalam jumlah besar tetapi tidak terhitung dalam sensus, sementara jenis-jenis ikan pelintas dengan ukuran populasi yang besar (schooling) sangat berpengaruh pada peningkatan biomassa ikan pada suatu wilayah.

Seperti dijumpai pada kelompok karang target, ikan indikator juga memiliki keanekaragaman wilayah cukup tinggi (30 species) pada seluruh lokasi penelitian pada perairan Taman Nasional Komodo. Sebaliknya keanekaragaman yang terbatas pada area transek saja dari lokasi ke lokasi lainnya tergolong sedang sampai rendah (Gambar 1). Menurut Suharti 
et al. (2014), pada penemuan 30 spesies pada seluruh lokasi penelitian tergolong keanekaragaman tinggi, tetapi pada penemuan di antara 20 - 10 species tergolong keanekaragaman sedang (lokasi MKDC 01, 03, 04, 05, 07 dan 09) dan di bawah 10 species tergolong rendah (lokasi MKDC 02, 06, 08, 10, 11 dan 12). Kondisi keanekaragaman wilayah ikan indikator sama seperti yang dijumpai di perairan Wakatobi (Tuti et al., 2018) atau malah lebih tinggi dari hasil survei Reef Health Monitoring di Sikka, Flores (Suharti \& Edrus, 2016). Namun keanekaragaman setempat di setiap stasiun untuk kelompok ikan indikator masih lebih rendah, karena hanya intensitas sebaran dari 4 jenis ikan indikator saja yang tergolong sangat tinggi dan tinggi di semua area penelitian. Hal ini menunjukkan bahwa sebaran jenis ikan indikator tidak merata. Sebaran ikan indikator sesuai dengan kompleksitas dan daya dukung substrat terumbu pada masing-masing lokasi taransek untuk kelompok yang bergantung pada polip karang atau sebagai obligate karang (Pratchett et al., 2006 ; 2013; Suharti, 2012). Komposisi jenis maupun kelimpahan individu ikan ini bergantung pada sifat fungsional dari suku ini yang dikategorikan sebagai coralivora yang bersifat obligate, facultative atau generalist dalam memilih makanannya (Adrim \& Hutomo, 1989; Pratchett et al., 2013). Untuk alasan itu, komposisi ikan ini dalam wilayah terumbu karang yang berbeda sangat bergantung pada kondisi substrat dan fauna karang itu sendiri yang menyediakan makan kegemarannya (Reese, 1981; Pratchett et al., 2006). Kelompok obligate pemakan karang keras selalu berhubungan lebih dekat dengan variasi spasial dari persen tutupan karang keras scleratinian, tetapi hal ini tidak ada pembatasan untuk kelompok fakultatif pemakan karang keras atau kelompok generalist bukan pemakan karang. Kelompok jenis yang memiliki spesialisasi tinggi pada pola makan tertentu, seperti jenis mangsa karang tertentu, akan terbatas mendiami pola zonasi tertentu saja yang khususnya memiliki kelimpahan terbesar dari mangsa yang disukai kelompok ikan ini. Untuk alasan tersebut, terdapat kaitan yang jelas antara spesialiasai pola makanan dengan pola komposisi jenis serta pola spasial dalam distribusi ikan kepekepe, dimana sebaran jenis ikan indikator yang tidak merata menyebabkan komposisi jenisnya pun rendah untuk masing-masing lokasi (Pratchett \& Berumen, 2008).

Pada wilayah terumbu karang di area tropis umumnya ditandai oleh kepadatan stok individual ikan karang yang rendah. Kepadatan stok 0,57 ekor $/ \mathrm{m}^{2}$ untuk ikan karang target dari hasil survei ini tergolong rendah untuk kriteria kepadatan stok yang ditetapkan oleh Djamali \& Darsono (2005). Namun kepadatan stok ini masih lebih tinggi jika dibanding hasil penelitian tahun 2013 di perairan Taman Nasional Komodo (Putra et al., 2013). Disamping itu, kepadatan stok kelompok ikan indikator di lokasi ini jauh lebih rendah jika dibandingkan hasil survei kesehatan karang dan ekosistem terkait di Wakatobi (Tuti et al., 2018). Jumlah individual ikan tidak selalu berhubugan dengan keanekaragaman ikan, tetapi berhubungan dengan sifat ukuran populasi ikan, terutama ada yang komposisinya lebih banyak bersifat individual (soliter) dibanding gerombolan (schooling) (Carpenter et al., 1981). Dalam hal ini, perairan karang Taman Nasional Komodo memiliki lebih banyak populasi dari jenisjenis yang bersifat soliter, baik untuk ikan karang target maupun indikator (Tuti et al., 2018) dan kelompok populasi schooling ikan target maupun indikator, seperti ekor kuning (Caesio spp. dan Pterocasio spp.) dan ikan indikator (Hemitaurichthys polylepis) ditemukan di area penelitian dalam ukuran populasi yang rendah. Hal ini berpengaruh pada angka kepadatan stok stok.

Dalam perbandingan biomassa ikan karang target, rata-rata biomassa $1.174 \pm 617 \mathrm{~kg} / \mathrm{ha}$ di perairan Taman Nasional Komodo adalah lebih rendah jika dibandingkan dengan rata-rata biomassa hasil survei di Wakatobi $(2.985 \pm 758 \mathrm{~kg} / \mathrm{ha}$ ) (Tuti, et al., 2017; 2018) tetapi lebih tinggi dari hasil survei di perairan Kabupaten Sikka (906 \pm 389 kh/ha) (Suharti \& Edrus, 2016) dan perairan karang Taman Nasional Komodo tahun 2013 (166 kg/ha) (Putra et al., 2013) atau hampir sama dengan hasil survei di Buton pada 2018 (1151 \pm 762) (Hadi et al., 2018). Perbedaan biomassa ikan antar lokasi tersebut dapat disebabkan antara lain oleh pola distribusi frekuensi panjang ikan, dimana pola sebaran frekuensi tersebut berhubungan dengan resultansi dari kelas-kelas intensitas penangkapan di suatu wilayah, seperti tinggi, sedang dan rendah. Pada intensitas penangkapan tinggi umumnya ukuran-ukuran ikan yang lebih besar menurun frekuensinya, sebaliknya ukuran tersebut meningkat pada wilayah dengan intensitas rendah (Sadovy et al., 2007). Kecuali itu, komposisi suku dan populasi ikan dari suku yang bersifat schooling dan berukuran relatif besar akan meningkatkan biomassa di suatu wilayah yang mendukung berkembangnya populasi tersebut. Seperti lebih lanjut di jelaskan di bawah ini.

Sumbangan terbesar biomassa berasal dari kelompok suku ikan mata besar/brajanata (Holocentridae) dan ekor kuning dan pisang-pisang (Caesionidae). Hal ini sama seperti yang dijumpai di perairan karang Kabupaten Sikka (Suharti \& Edrus, 2016). Tidak banyak jenis ikan karang ekonomis penting yang memiliki ukuran panjang di atas $30 \mathrm{~cm}$ seperti umumnya dijumpai pada kelompok kerapu (Serranidae), kakap (Lutjanidae), lencam (Lethrinidae), 
bibir tebal (Haemulidae), kakatua (Scaridae), dan kuwe (Carangidae). Umumnya kurva sebaran panjang ikan memiliki sifat sebaran normal (Gambar 6), tetapi kurva sebaran lebih condong ke kiri, karena modus terbanyak umumnya di bawah ukuran panjang $30 \mathrm{~cm}$. Menurut Sodovy et al. (2007) hal ini menunjukkan adanya intensitas penangkapan yang relatif tinggi untuk suatu wilayah, dimana ikan-ikan berukuran besar banyak tertangkap, sehingga tinggi rendahnya biomassa ikan pada suatu wilayah sangat bergantung pada distribusi ukuran panjang ikan, aktivitas penangkapan, ukuran populasi ikan, daerah asuhan dan daerah tangkapan ikan.

\section{KESIMPULAN}

Komposisi jenis ikan pada perairan terumbu karang Taman Nasional Komodo terdiri dari: 128 spesies ikan karang target dan 30 spesies ikan indikator dan diantaranya hanya 14 spesies ikan target dan 10 spesies ikan indikator yang secara individual mendominasi komunitasnya. Sebaran jenisjenis ikan target dan ikan indikator tidak merata pada seluruh lokasi penelitian. Distribusi jenis ikan target adalah 3\% sangat tinggi, $7 \%$ tinggi, $18 \%$ sedang, $21 \%$ rendah dan $51 \%$ sangat rendah dan kategori untuk sebaran ikan indikator adalah $7 \%$ sangat tinggi dan tinggi, $23 \%$ sedang, $40 \%$ rendah dan $23 \%$ sangat rendah. Rata-rata kepadatan ikan karang target adalah $182 \pm 67$ ekor $/ 350 \mathrm{~m}^{2}$ dan ikan indikator $35 \pm$ 15 ekor/ $350 \mathrm{~m}^{2}$. Rata-rata biomassa ikan karang target adalah $1.174 \pm 617 \mathrm{~kg} / \mathrm{h}$ hektar dengan variasi yang lebar antar stasiun penelitian, dimana penyumbang tertinggi biomassa di antara ikan target sebanyak 14 spesies.

\section{PERSANTUNAN}

Kegiatan ini merupakan bagian dari kegiatan Pusat Penelitian Oseanografi-LIPI berkaitan Survei Ikan Karang di Pulai Komodo T.A 2019. Terima kasih diucapkan kepada semua pihak yang telah membantu kelancaran kegiatan ini.

\section{DAFTAR PUSTAKA}

Acosta, C. A., \& Robertson. D.N. (2002). Diversity in coral reef fish communities: the effects of habitat patchiness revisited. Marine Ecology Progress Series, 227, 87-96. https://www.jstor.org/stable/ 24864943

Adrim, M., \& Hutomo, M. (1989). Species composition, distribution and abundance of Chaetodontidae along reef transect in the Flores Sea. Nederland Journal of Sea Research, 23 (2), 85-93. https:// doi.org/10.1016/0077-7579(89)90003-3
Allen, G.R., \& Erdmann, MV. (2012). Reef Fishes of the East Indies. $1^{\text {st }}$ Vol to 3rd Vol. (p. 1.260). Perth, Australia: Tropical Reef Research.

Amesbury, S. S. (1981). Effects of turbidity on shallow-water reef fish assemblages in Truk, Eastern Caroline Islands. Proc. Fourth Int. Coral Reef Symp., Manilla 1, 155-159. http:// www.reefbase.org/resource_center/publication/ icrs.aspx?icrs=ICRS4

Carpenter, K.E., Miclat, R.I., Albaladejo, V.D. \& Corpuz, V.T. (1981). The influence of substrate structure on the local abundance and diversity of Philippine reef fishes. Proc. Fourth Int. Coral Reef Symp., Manila 2, 497-502.

Cheney, K. L. \& Côté, I.M. (2003). Habitat choice in adult longfin damselfish: territory characteristics and relocation times. Journal of Experimental Marine Biology and Ecology, 287, 1-12. https:// doi.org/10.1016/S0022-0981(02)00500-2

Djamali, A., \& Darsono, P. (2005). Petunjuk teknis Lapangan untuk Penelitian Ikan Karang di Ekosistem terumbu Karang. Materi Kursus. Jakarta: Pusat Dokumentasi dan Informasi IImiah-LIPI.

Edrus, I.N., \& Setyawan, I.E. (2013). Pengaruh kecerahan air laut terhadap struktur komunitas ikan karang di perairan pulau Belitung. J. Lit. Perikan. Ind, 19 (2), 55-64.

Edrus, I.N., \& Suharti, R.S. (2016). Sumber daya ikan karang di Taman Wisata Alam Gili Matra, Lombok Barat. J. Lit. Perikan. Ind. 2 (4), 225-242. doi.10.14203/oldi. 2018.v3i2.112

Edrus, I.N., \& Hadi, T. A. (2019). Struktur komunitas ikan karang di perairan Belitung. Makalah pada Indonesian Coral Reef Conference, Semarang 4 Juli 2019 (19 hal). Semarang : UNDIP _ COREMAP-CTI-LIPI.

English, S., Wilkinson, C., \& Baker, V. (1994). Survei manual for Tropical marine Resources. Townsville, Australia: Australian Institute of Marine Science.

Feary, D.A., Almany, G.R., Jones, G.P., \& McCormick, M.I. (2007). Coral degradation and the structure of tropical reef Fish communities. Mar. Ecol. Prog. Ser. 333, 243-248. DOI: 10.3354/meps333243

Froese, R., \& Pauly, D. Editors. (2014). FishBase. World Wide Web electronic publication. www.fishbase.org, version (04/2014). 
Ferreira, C. E. L., Gonçalves, J. E. A., \& Coutinho, R. (2001). Community structure of fishes and habitat complexity in a tropical rocky shore. Environmental Biology of Fishes, 61, 353-369. https:// doi.org/ 10.1023/A:1011609617330

Green, A.L. (1996). Spatial, temporal and ontogenetic patterns of habitat use by coral reef Fishes (family Labridae). Mar. Ecol. Prog. Ser. 133, 1-11. doi:10.3354/meps 133001

Hadi, T.A., Suharsono, Tuti, M.I.Y., Abrar, M., Sulha, S., Cappenberg, H.A.W., Putra, M.Y. Edrus, I.N. ..... (2018). Monitoring Kesehatan Terumbu Karang dan Ekosistem Terkait lainnya; Kepulauan Buton, Sulawesi Tenggara 2017 (98 hal). Jakarta: COREMAP-CTI, P2O-LIPI.

Jones, G.P., McCormick, M.I., Srinivasan, M., \& Eagle, J.V. (2004). Coral decline threatens fish biodiversity in marine reserves. Proc. Natl. Acad. Sci. USA 101, 8251-8253.

Joyeux, J. C., Floeter, S. R., Ferreira, C. E. L., \& Gasparini, J. L. (2001). Biogeography of tropical reef fish: the South Atlantic puzzler. Journal of Biogeography, 28, 1-11. https://doi.org/10.1046/ j.1365-2699.2001. 00602.x

Kawasaki, H., Sano, M., \& Shibuno, T. (2003). The relationship between habitat physical complexity and recruitment of the coral reef damselfish, Pomacentrus amboinensis: an experimental study using small-scale artificial reefs. Ichthyology $R e$ search, 50, 73-77.https://doi.org/10.1007/s1022 80300010

Kuiter, R.H. \& Tonozuka, T. (2001). Pictorial Guide to: Indonesian Reef Fishes. Australia: Zoonetics Publc. Seaford VIC 3198.

Luckhurst, B. E., \& Luckhurst, K. (1978). Analysis of the influence of substrate variables on coral reef fish communities. Mar. Biol. 49, 317-323.

Maeilana, R. (2017). Banyak wisatawan nakal, Terumbu Karang Pulau Komodo Terancam Bernasib seperti Raja Ampat. Kabar Nasional. Tersedia pada https://kbr.id/ nasional/05-2017/ banyak_wisatawan_ karang_pulau nakal_terumbu_ - komodo terancam_bernasib_seperti_raja_ampat/90123. html. Accesed 11 May 2017.

Mallela, J., Roberts, C., Harrod, C., \& Goldspink, C.R. (2007). Distributional patterns and community structure of Caribbean coral reef fishes within a river-impacted bay. Journal of Fish Biology 70, 523537. https://doi.org /10.1111/j.10958649.2007.01323.x

Neto, J.P.deM, Neto, C.M., \& Moraes, L.E. (2008). Reef fish community structure on three Islands of Itaipu, Southeast Brazil. Neotropical Ichthyology, 6 (2), 267-274. http://dx.doi.org/10.1590/S167962252008000200015

NOAA (2019). Coral Reefs in the Pacific. Providing scientific information to support ecosystem approaches to management and conservation of coral reefs. Last updated on 03/11/2019

Obura, D.O., \& Grimsdith, G. (2009). Resilience Assessment of coral reefs - Assessment protocol for coral reefs, focusing on coral bleaching and thermal stress (p. 70). Gland, Switzerland: IUCN working group on Climate Change and Coral Reefs.

Pratchett, M.S., Wilson, S.K., \& Baird, H. (2006). Declines in the abundance of Chaetodon butterflyfishes following extensive coral depletion. Journal of Fish Biology, 69(5), 1269 1280. https://doi.org /10.1111/j.1095-8649.2006. 01161.x

Pratchett, M.S,. \& Berumen, M.L. (2008). Interspecific variation in distributions and diets of coral reef butterflyfishes (Teleostei: Chaetodontidae). Journal of Fish Biology, 73(7), 1730-1747. https:// doi.org/10.1111/j.1095-8649.2008.02062.x

Pratchett, M. S., Graham, N.A.J. \& Cole, A.J. (2013). Specialist corallivores dominate butterflyfish assemblages in coral dominated reef habitats. Journal of Fish Biology, 82(4), 1177-1191. doi: 10.1111/ jfb.12056.

Putra, H.M.I., Zirzis, M.G., Siahaan, J.E.N., Tarigan, S., Saputra, T.A. Saputra, J., Ihsan, E.N., \& Riayanto, A.E. (2013). Laporan Monitoring Kesehatan Karang dan Survei Dive Site, Taman Nasional Komodo, NTT, April 2013. Technical Report (p. 68I). Semarang : Universitas Diponegoro Publ.

Roberts, C.M., \& Ormond, R.F.G. (1987). Habitat complexity and coral reef fish diversity and abundance on Red Sea fringing reefs. Marine Ecology, $41,1-8$.

Suharti, S. R., Wibowo, K., Edrus, I, N., \& Fahmi. (2014). Monitoring Ikan Karang in Panduan Moni- 
toring Kesehatan Terumbu Karang. Coremap-CTI. Lembaga Ilmu Pengatahuan Indonesia.

Suharti, S.R., \& Edrus, I.N. (2016). Karakteristik ikan karang di kawasan konservasi perairan daearah Kabupaten Sikka, Flores. Dalam: Prosiding Seminar Nasional Ikan Ke 9, Jakarta 24 Mei 2016 (p. 968). Jakarta: Masyarakat Iktiologi Indonesia.

Suharti, R. (2012). Hubungan kondisi Terumbu Karang dengan Kelimpahan Ikan Chaetodontidae di Pulau Karang Bongkok Kepulauan Seribu. Thesis Program Pasca Sarjana. Universitas Terbuka.

Syms, G., \& Jones, G. P. (2000). Disturbance, habitat structure and the dynamics of a coral-reef fish community. Ecology 81 (10), 2714 - 2729. DOI: $10.2307 / 177336$

Tuti, M.I.Y., Suharti, S.R., Cappenberg, H.A.W., Edrus, I.N., Darmawan, I.W.E., Hadi, T.A., Utama, R.S., Budianto, A., Salatalohi, A., \& Sulha, S. (2017). Monitoring kesehatan terumbu karang dan ekosistem terkait lainnya: di Kabupaten Wakatobi, Sulawesi Tenggara 2017 (p. 119). Jakarta: COREMAP-CTI, P20-LIPI.
Tuti, M.I.Y., Suharsono, Suharti, S.R., Cappenberg, H.A.W., Edrus, I.N., Hadi, T.A., Utama, R.S., Rachmawati, S., Darmawan, I.W.E., Sulha, S., Budianto, A., Salatalohi, A. \& Hadiyanto, M. (2018). Monitoring kesehatan terumbu karang dan ekosistem terkait di Kabupaten Wakatobi 2018 (p. 89). Jakarta: COREMAP-CTI, P20-LIPI.

Wismabrata, M.H. (2018). Ekosistemnya Rusak, Taman Nasional Komodo Jadi Perhatian UNESCO. Kompas.com. Editor: Shierine Wangsa Wibawa. Tersedia pada https://sains.kompas.com/read/ 2018/04/21/ 100500623/ekosistemnya-rusaktaman-nasional-komodo-jadi-perhatian-unesco?page=all. Accessed 21 April 2018.

Wilson, J.R., \& Green, A.L. (2009). Metode pemantauan biologi untuk menilai kesehatan terumbu karang dan efektivitas Pengelolaan Kawasan Konservasi Laut di Indonesia (Terjemahan). Versi 1.0. Laporan TNC Indonesia Marine Program No 1/09. 46 hal. 
Lampiran 1. Posisi geografis lokasi

Appendix 1. Geographis Position of location

\begin{tabular}{clll}
\hline $\begin{array}{c}\text { Kode Stasiun (Station } \\
\text { Codes) }\end{array}$ & \multicolumn{1}{c}{ Lokasi (Location) } & Latitude & Longitude \\
\hline KMDC01 & P. Pungu & -8.52822 & 119.79884 \\
KMDC02 & P. Sebayur Besar & -8.50275 & 119.73343 \\
KMDC03 & P. Siaba Besar & -8.54505 & 119.64964 \\
KMDC04 & P. Komodo, Gili Lawa & -8.47694 & 119.55887 \\
KMDC05 & P. Kelor, Karang Makasar & -8.53471 & 119.58047 \\
KMDC06 & P. Komodo, Loh Gung & -8.66857 & 119.44372 \\
KMDC07 & P. Padar & -8.64567 & 119.57043 \\
KMDC08 & P. Rinca, TanjungLohKima & -8.66111 & 119.66784 \\
KMDC09 & P. Rinca, LohLinga & -8.61952 & 119.74221 \\
KMDC10 & P. Papagarang & -8.56631 & 119.72136 \\
KMDC11 & P. Gado (Strawbery) & -8.60012 & 119.79187 \\
KMDC12 & P. Papagarang Kecil & -8.58168 & 119.74258 \\
\hline
\end{tabular}

Lampiran 2. Peta Lokasi Penelitian, Perairan Taman Nasional Komodo, Nusa Tenggara Timur Appendix 2. Map showing the study sites, The Komodo National Park Waters, Nusa Tenggara timur

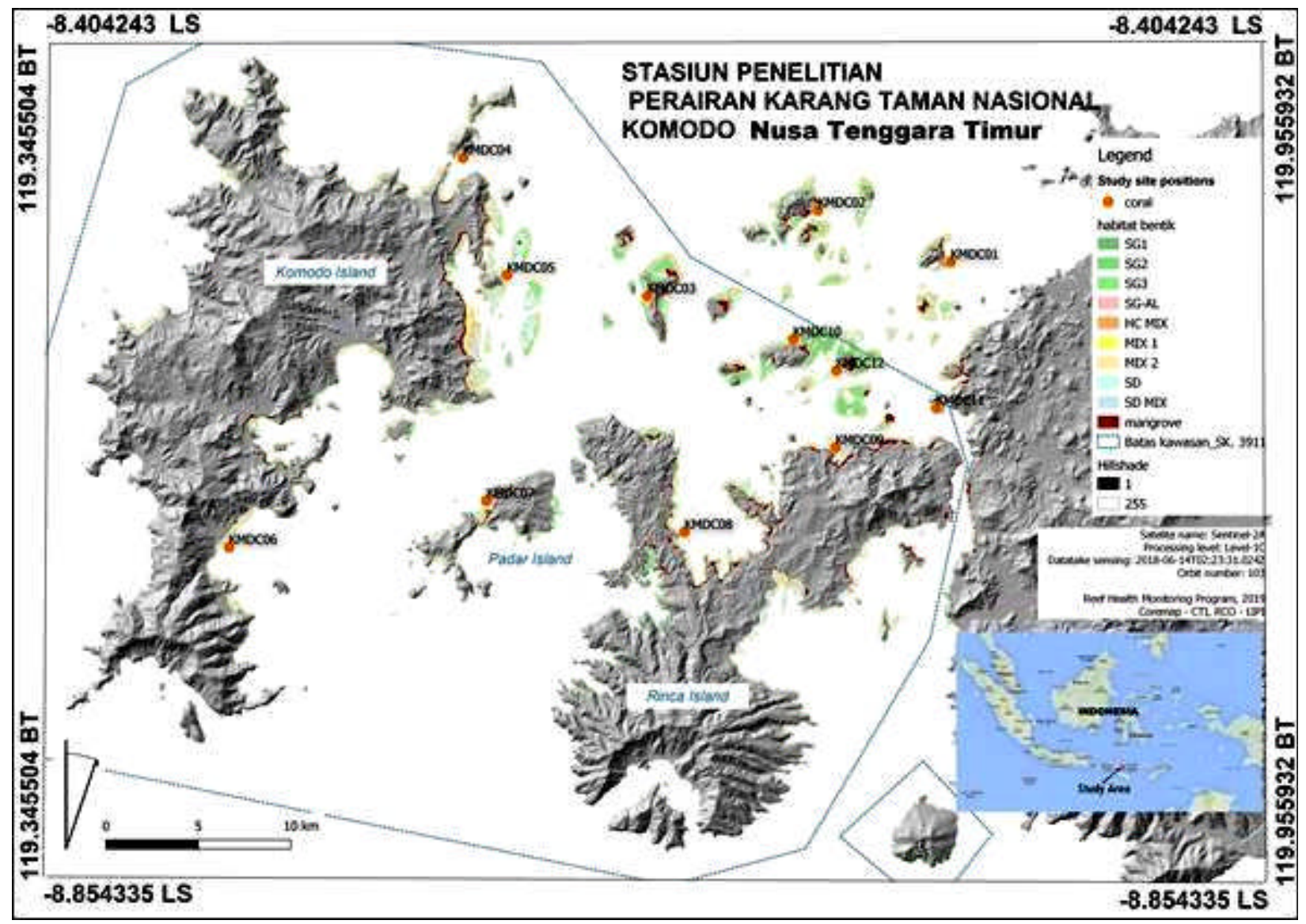

